\title{
Episodic Bursting Activity and Response to Excitatory Amino Acids in Acutely Dissociated Gonadotropin-Releasing Hormone Neurons Genetically Targeted with Green Fluorescent Protein
}

\author{
M. Cathleen Kuehl-Kovarik, Wendy A. Pouliot, Gloriana L. Halterman, Robert J. Handa, F. Edward Dudek, \\ and Kathryn M. Partin
}

Department of Anatomy and Neurobiology, Colorado State University, Fort Collins, Colorado 80523-1670

The gonadotropin-releasing hormone $(\mathrm{GnRH})$ system, considered to be the final common pathway for the control of reproduction, has been difficult to study because of a lack of distinguishing characteristics and the scattered distribution of neurons. The development of a transgenic mouse in which the $\mathrm{GnRH}$ promoter drives expression of enhanced green fluorescent protein (EGFP) has provided the opportunity to perform electrophysiological studies of $\mathrm{GnRH}$ neurons. In this study, neurons were dissociated from brain slices prepared from prepubertal female GnRH-EGFP mice. Both current- and voltageclamp recordings were obtained from acutely dissociated $\mathrm{GnRH}$ neurons identified on the basis of EGFP expression. Most isolated GnRH-EGFP neurons fired spontaneous action potentials (recorded in cell-attached or whole-cell mode) that typically consisted of brief bursts $(2-20 \mathrm{~Hz})$ separated by $1-10$ sec. At more negative resting potentials, GnRH-EGFP neurons exhibited oscillations in membrane potential, which could lead to bursting episodes lasting from seconds to minutes. These bursting episodes were often separated by minutes of inactivity. Rapid application of glutamate or NMDA increased firing activity in all neurons and usually generated small inward currents $(<15 \mathrm{pA})$, although larger currents were evoked in the remaining neurons. Both AMPA and NMDA receptors mediated the glutamate-evoked inward currents. These results suggest that isolated $\mathrm{GnRH}$-EGFP neurons from juvenile mice can generate episodes of repetitive burst discharges that may underlie the pulsatile secretion of $\mathrm{GnRH}$, and glutamatergic inputs may contribute to the activation of endogenous bursts.

Key words: glutamate; GFP; GnRH; burst; episodic activity; acute dissociation
The neuroendocrine cells that secrete gonadotropin-releasing hormone $(\mathrm{GnRH})$ integrate synaptic inputs and generate action potentials that regulate pulsatile secretion of gonadotropic hormones from the anterior pituitary (Kalra and Kalra, 1983; Sagrillo et al., 1996; Terasawa, 2000). The GnRH neurons are small and dispersed throughout the hypothalamus and adjacent areas (Barry et al., 1985; Silverman et al., 1987, 1994) and therefore have primarily been considered intractable for electrophysiological studies. Cultured embryonic neurons or tumor cell lines (e.g., GT1-7 cells) have been used to study the GnRH system (Mellon et al., 1991; Wetsel et al., 1992; Kusano et al., 1995; Terasawa et al., 1999a). However, both of these model systems have serious technical and conceptual limitations (Selmanoff, 1997; Herbison, 2001; Terasawa, 2001). Sim et al. (2001) have attempted to visually identify unlabeled GnRH neurons in a slice, followed by post hoc reverse transcription (RT)-PCR; however, GnRH neurons are morphologically similar to non-GnRH neurons, and singlecell RT-PCR in slices has potential for false positives. Recently, genetic targeting of green fluorescent protein (GFP) to GnRH neurons has allowed electrophysiological studies with the brain-

Received Oct. 24, 2001; revised Dec. 13, 2001; accepted Jan. 3, 2002.

This study was funded by National Institutes of Health Grant AA12693 to R.J.H., National Institutes of Health Grant MH 59995 and College of Veterinary Medicine and Biomedical Sciences (CVMBS) College Research Council to F.E.D., and a CVMBS Veterinary Summer Research Fellowship to G.L.H. We thank Dr. Sue Moenter (University of Virginia) for generously providing the GnRH-EGFP transgenic mice. M.C.K.-K. thanks Drs. Trussell and Ribera for sharing their expertise at Cold Spring Harbor Laboratories.

Correspondence should be addressed to M. Cathleen Kuehl-Kovarik, 200 West Lake Street, Department of Anatomy and Neurobiology, Colorado State University, Fort Collins, CO 80523-1670. E-mail: cathy.kovarik@colostate.edu.

Copyright (C) 2002 Society for Neuroscience $0270-6474 / 02 / 222313-10 \$ 15.00 / 0$ slice preparation (Spergel et al., 1999, 2001; Suter et al., 2000a,b; Dudek et al., 2001). This approach has been useful for analyzing episodic activity and transmitter receptor mechanisms. We used whole-cell and cell-attached recording from acutely dissociated GnRH-EGFP (enhanced GFP) neurons to study burst generation, episodic electrical activity, and responses mediated by glutamate receptors.

Neuroendocrine cells generate bursts of action potentials that facilitate hormone secretion (Dudek et al., 1989, 2000; Bourque et al., 1993; Branshaw et al., 1998). Multiple-unit recordings have shown that pulsatile secretion of GnRH is correlated with population discharge from hypothalamic neurons (i.e., hypothetical GnRH neurons and their associated neural network) (Kawakami et al., 1982; Wilson et al., 1984; Mori et al., 1991; Cardenas et al., 1993; Nishihara et al., 1999). Relatively little, however, is known about this mechanism at the level of the single GnRH neuron. Experiments on hormone release and multiple-unit recordings lack temporal and spatial resolution, preventing a determination of the firing patterns of individual neurons. Recently, Suter and coworkers (2000b) observed burst firing and episodic activity in GnRH-EGFP neurons using whole-cell recordings in preoptic/ hypothalamic slices, which suggests that single GnRH neurons can generate burst discharges and episodic activity that could underlie pulsatile secretion.

Glutamate is an important regulator of neuroendocrine secretion in the mammalian hypothalamus (van den Pol et al., 1990; Sagrillo et al., 1996) (for review, see Brann and Mahesh, 1997). In vivo injections of glutamate and NMDA activate reproductive mechanisms (Arslan et al., 1988; Ondo et al., 1988; Bourguignon et al., 1989). However, in studies of GnRH-GFP neurons using 
the outside-out nucleated patch configuration, NMDA responses were found in only $20 \%$ of cells (Spergel et al., 1999). Anatomical evidence suggests that GnRH neurons receive glutamatergic input and express multiple glutamate receptor subtypes (Goldsmith et al., 1994; Abud and Smith, 1995; Thind and Goldsmith, 1995; Eyigor and Jennes, 1996; Gore et al., 1996). Individual GnRH neurons are thought to have relatively few synapses (Witkin et al., 1995). In the present studies, we examined the hypothesis that isolated $\mathrm{GnRH}$ neurons could generate repetitive bursts of activity and that glutamate or NMDA could directly activate these neurons.

\section{MATERIALS AND METHODS}

Acute dissociation of neurons. Female GnRH-EGFP transgenic mice (Suter et al., 2000a), postnatal day 17 (P17) to P25, were used for all experiments: data were collected from five cells isolated from P17, 10 from P18, seven from P19, seven from P20, 13 from P22, six from P23, and 10 from P25. All protocols were approved by the Animal Care and Use Committee at Colorado State University. Mice were anesthetized with halothane and decapitated. Brains were rapidly removed and placed in cold oxygenated artificial CSF (ACSF) (in mM: $124 \mathrm{NaCl}, 3 \mathrm{KCl}, 2$ $\mathrm{MgSO}_{4}, 1.25 \mathrm{NaH}_{2} \mathrm{PO}_{4}, 26 \mathrm{NaHCO}_{3}, 10$ dextrose, and $2.5 \mathrm{CaCl}_{2}, \mathrm{pH}$ 7.4). Coronal brain slices $(400 \mu \mathrm{m})$ were cut with a vibratome in ice-cold ACSF. Slices were maintained in ACSF (aerated with $95 \% \mathrm{O}_{2}, 5 \% \mathrm{CO}_{2}$ ) at $32^{\circ} \mathrm{C}$ for $1-6 \mathrm{hr}$ before dissociation. The acute dissociation procedure was a modification of previously established protocols (Kay and Krupa, 1999) (McCool and Botting, 2000). Regions of the brain including the medial preoptic area and diagonal band of Broca were dissected from the slices (Fig. 1). Neuronal activity was measured in 30 neurons that had been isolated from slices of the diagonal band of Broca, 24 neurons from the medial preoptic area, and four neurons that were isolated from slices that included both areas. No differences were observed for neurons isolated from the two different regions. Slices were placed in proteinase $\mathrm{K}(0.2 \mathrm{mg} / \mathrm{ml}$; Sigma, St. Louis, MO) in PIPES buffer [in mM: $115 \mathrm{NaCl}$, $5 \mathrm{KCl}, 20$ PIPES free acid, $1 \mathrm{CaCl}_{2}, 4 \mathrm{MgCl}_{2}$, and 25 dextrose, $\mathrm{pH} 7.0$ (aerated with $100 \% \mathrm{O}_{2}$ )] at $30^{\circ} \mathrm{C}$ for $5 \mathrm{~min}$, rinsed in PIPES buffer, and placed in trypsin (Sigma type XI; $1 \mathrm{mg} / \mathrm{ml}$ ) in PIPES buffer at $30^{\circ} \mathrm{C}$ for 22-25 min. Slices were rinsed four to five times in PIPES buffer, and neurons were isolated by trituration with flame-polished Pasteur pipettes in ice-cold PIPES buffer containing 0.1\% DNase. The resulting solution was diluted 1:1 with Neurobasal A/B-27 (Invitrogen, Grand Island, NY). Cells were plated on charged plastic culture dishes, incubated at $37^{\circ} \mathrm{C}$ $\left(95 \% \mathrm{O}_{2}, 5 \% \mathrm{CO}_{2}\right)$ for $20-30 \mathrm{~min}$ to allow adherence, rinsed, and covered with Neurobasal A/B-27. Neurons were incubated for 17-24 hr before electrophysiological recordings.

The presence of $1 \mathrm{mM} \mathrm{CaCl}$ during the isolation and trituration of tissue prevents the retention of presynaptic boutons on the dissociated neurons (Drewe et al., 1988). To exclude the possibility that membrane oscillations were attributable to synaptic events, experiments with $10 \mu \mathrm{M}$ CNQX, $50 \mu \mathrm{M} \mathrm{APV}$, and $30 \mu \mathrm{M}$ bicuculline showed that these blockers did not alter the occurrence of membrane oscillations (data not shown). These experiments confirm that transmitter release from presynaptic terminals did not influence the activity of the isolated neurons.

Immunocytochemistry. Dissociated neurons were plated on poly-Dlysine-coated two-chamber slides, covered in Neurobasal A/B-27, and incubated at $37^{\circ} \mathrm{C}\left(95 \% \mathrm{O}_{2}, 5 \% \mathrm{CO}_{2}\right)$ overnight. Cells were rinsed with $1 \times$ PBS and then fixed for 20 min at room temperature with freshly made $4 \%$ paraformaldehyde. Cells were again washed with PBS, three times for 2 min each. Cells were incubated in blocking solution $(1.5 \%$ normal goat serum, $0.4 \%$ Triton-X, and $1 \%$ Fraction V bovine serum albumin in PBS) for $1 \mathrm{hr}$ at room temperature. After another wash in PBS, the cells were incubated with GnRH antibody [1:2000, luteinizing hormonereleasing hormone (LHRH) antibody in PBS with $1 \%$ Triton-X; DiaSorin, Stillwater, MN] overnight at $4^{\circ} \mathrm{C}$. Cells were rinsed with PBS, three times for $5 \mathrm{~min}$ each. AlexaFluor 594-conjugated goat anti-rabbit secondary antibody (Molecular Probes, Eugene, OR) was applied to the cells at a concentration of $5 \mu \mathrm{g} / \mathrm{ml}$ for $30 \mathrm{~min}$ at room temperature. Slides were rinsed twice with PBS and once with deionized water and then mounted with Vectashield (Vector Laboratories, Burlingame, CA) for viewing. Photomicroscopy was performed on either a Zeiss (Oberkochen, Germany) confocal microscope (live cells) or a Zeiss Axioplan 2 (fixed cells). Preincubation of the primary antibody with 10 $\mu \mathrm{g} / \mathrm{ml}$ purified LHRH peptide (Sigma) in diluted antiserum for $60 \mathrm{~min}$,

\section{A. Rostral}
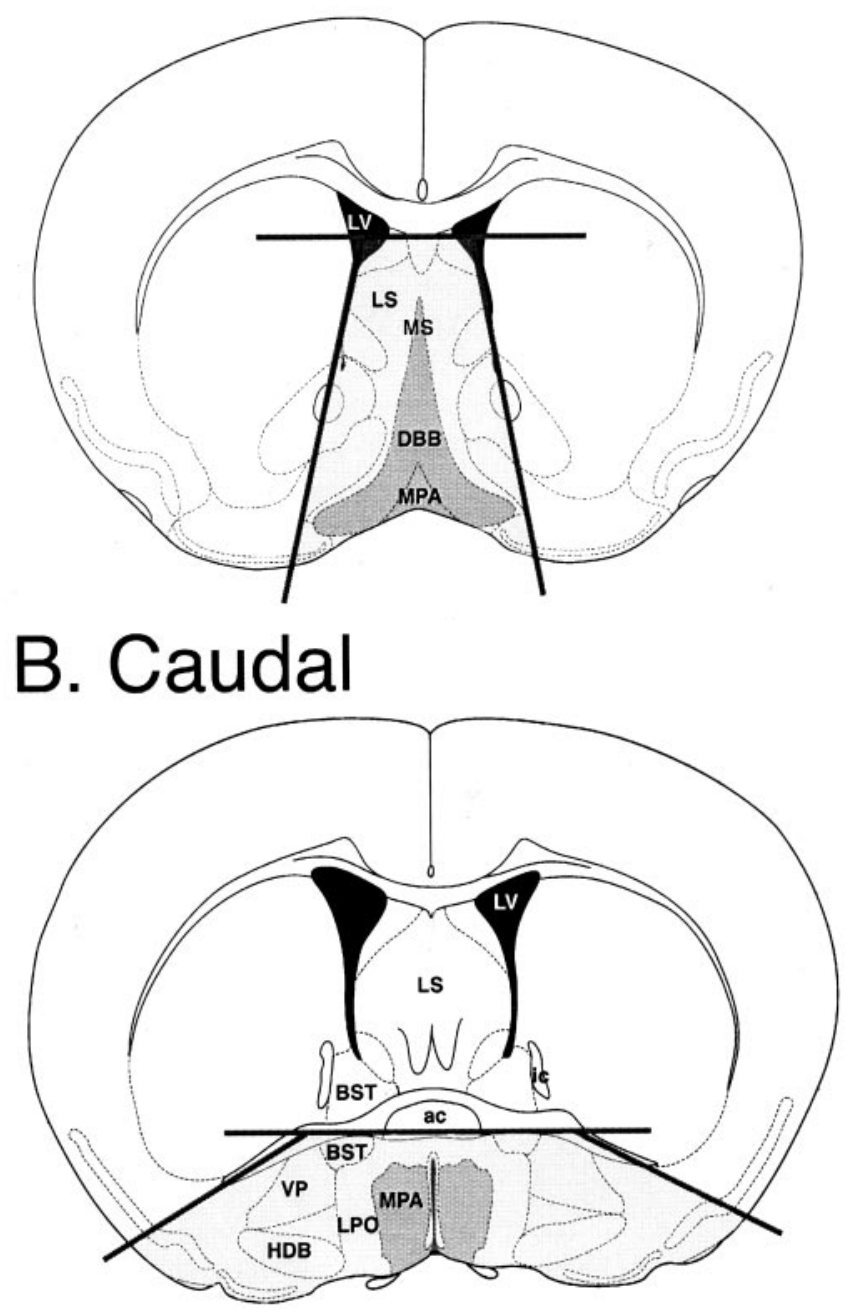

Figure 1. Dissociation of GnRH-EGFP neurons from brain slices. Neurons were isolated from $400-\mu \mathrm{m}$-thick hypothalamic slices that included the diagonal band of Broca $(D B B)$ and surrounding septum $(A$, Rostral $)$ or the medial preoptic area $(M P A)$ and surrounding hypothalamus $(B, C a u-$ $d a l)$. Two to three slices were taken per animal. Dark gray indicates the area with the highest concentration of GnRH neurons, although cells are also scattered throughout surrounding areas (light gray). Dark lines represent the cuts made to isolate the region before enzymatic treatment. Atlas figures were modified from Franklin and Paxinos (1997) with permission. $a c$, Anterior commissure; $B S T$, bed nucleus of the stria terminalis; $H D B$, horizontal limb of the diagonal band of Broca; $i c$, internal capsule; $L P O$, lateral preoptic area; $L S$, lateral septum; $L V$, lateral ventricle; $M S$, medial septum; $V P$, ventral pallidum.

before incubation with the neurons, resulted in the absence of all fluorescence under the rhodamine filter, as did the omission of anti-LHRH primary antibody. In one experiment, neurons were counted from six visual fields: a total of 311 neurons were present, of which six were EGFP-positive (2\%), and the same six (and no other cells) were immunoreactive for GnRH.

Electrophysiology. Culture dishes were continuously perfused with ACSF at $22^{\circ} \mathrm{C}$. Fluorescent cells were viewed with a mercury lamp. Cell-attached and whole-cell recordings were obtained with thin-walled borosilicate glass micropipettes (World Precision Instruments, Sarasota, FL) with a resistance of 3-5 M $\Omega$. The intracellular recording solution consisted of (in mM): 120 potassium gluconate, $1 \mathrm{CaCl}_{2}, 1 \mathrm{MgCl}_{2}, 10$ HEPES, $1 \mathrm{NaCl}, 5$ EGTA, and 2 ATP, $\mathrm{pH}$ 7.2-7.4. All recordings were performed using an Axopatch 200B (Axon Instruments, Foster City, CA), digitized at $0.1-0.2 \mathrm{msec} /$ point, and stored on a Power Macintosh 
computer (Apple Computers, Cupertino, CA) using an ITC-16 interface (InstruTech, Port Washington, NY). All data were acquired with Synapse (Synergistic Research, Newport Beach, CA) software. Some current-clamp recordings were also digitized with a VR-10B (InstruTech) and stored on videocassette for off-line analysis.

Current-clamp recordings were obtained from cells adhered to the bottom of the dish. When monitoring spontaneous activity, cells at a resting membrane potential less negative than $-60 \mathrm{mV}$ were hyperpolarized with current injection after 10-20 min to determine activity at more negative potentials. All voltage-clamp recordings were obtained at a holding potential of $-60 \mathrm{mV}$. Voltage-clamp recordings were obtained from cells attached to the bottom of the dish and cells lifted by the patch pipette. A liquid junction potential of $\sim 5 \mathrm{mV}$ was determined and was not corrected for in the numbers reported. Rapid perfusion of agonists was performed with a flow pipe constructed from $\theta$ tubing (Sutter Instruments, Novato, CA) driven by a piezoelectric device (Burleigh Instruments, Fishers, NY). Neurons were placed in a control solution stream (160 mm NaCl, $2.5 \mathrm{~mm} \mathrm{KCl}, 10 \mathrm{~mm}$ HEPES, $10 \mathrm{~mm}$ dextrose, 2 $\mathrm{mm} \mathrm{CaCl} 2,10 \mu \mathrm{M}$ glycine, and $0.1 \mathrm{mg} / \mathrm{ml}$ phenol red) and then rapidly jumped into $10 \mathrm{~mm}$ glutamate, $10 \mathrm{~mm}$ glutamate plus $100 \mu \mathrm{M}$ cyclothiazide (20 mM stock solution dissolved in DMSO), or $300 \mu \mathrm{M}$ NMDA for $500 \mathrm{msec}$. DMSO was added so that all solutions contained equivalent amounts of vehicle. Solution flow was driven by a syringe pump (KD Scientific, New Hope, NY) at a rate of $0.2 \mathrm{ml} / \mathrm{min}$. All drugs were obtained from Research Biochemicals (Natick, NY).

Data analysis. Images of neurons were captured with a CCD camera (Hitachi, Tokyo, Japan) and measured using Scion NIH Image 1.62. Current traces, agonist-evoked current responses, and histograms were plotted using KaleidaGraph 3.5 (Synergy Software, Reading, PA). Analysis of activity and agonist-evoked currents was performed with Synapse software (Synergistic Research). Statistical analyses were performed using Microsoft (Seattle, WA) Excel (ANOVA) and Minitab (linear regression analyses; State College, PA). Data are presented as mean \pm SEM.

\section{RESULTS}

\section{Acute dissociation of GnRH-EGFP neurons}

Fluorescent GnRH-EGFP neurons could be positively identified immediately after dissociation, and fluorescence was detectable for at least $3 \mathrm{~d}$ after the dissociation, the longest time examined (most electrophysiological experiments were performed 17-24 hr after the dissociation). Fluorescent neurons could be readily identified in the culture dish, either as individual neurons or in a group of cells. Only slight variations in diameter (mean of $14 \mu \mathrm{m}$; range of $10-17 \mu \mathrm{m} ; n=41$ ) and intensity of fluorescence were noted. Healthy GnRH-EGFP neurons appeared phase bright and were typically round (Fig. $2 A$ ), although some had rudimentary processes. In parallel experiments, dissociated cells were fixed for immunocytochemistry using anti-GnRH primary antibody and AlexaFluor-conjugated secondary antibody (Fig. 2B). Cells that were positive for EGFP fluorescence were also positive for GnRH immunoreactivity, whereas the more numerous, nonfluorescing cells were negative for GnRH immunoreactivity. This indicates that EGFP expression occurred only in GnRH neurons, and therefore the neurons that were recorded represent the target GnRH population. When patch clamped in the whole-cell configuration, the typical resting membrane potential was -50 to $-55 \mathrm{mV}(52.5 \pm 2.62 ; n=16)$, although the resting membrane potential could be as negative as $-80 \mathrm{mV}$. GnRH-EGFP neurons had cell membrane properties of healthy neurons, with an average input resistance of $2.44 \pm 0.23 \mathrm{G} \Omega$.

\section{Spontaneous activity}

Action potentials were observed in 90\% (27 of 30) of GnRHEGFP neurons during long current-clamp recordings, although a few did not exhibit spontaneous activity at any membrane potential. Spontaneous activity was recorded in both cell-attached and whole-cell configurations. In cell-attached recordings, spontane-
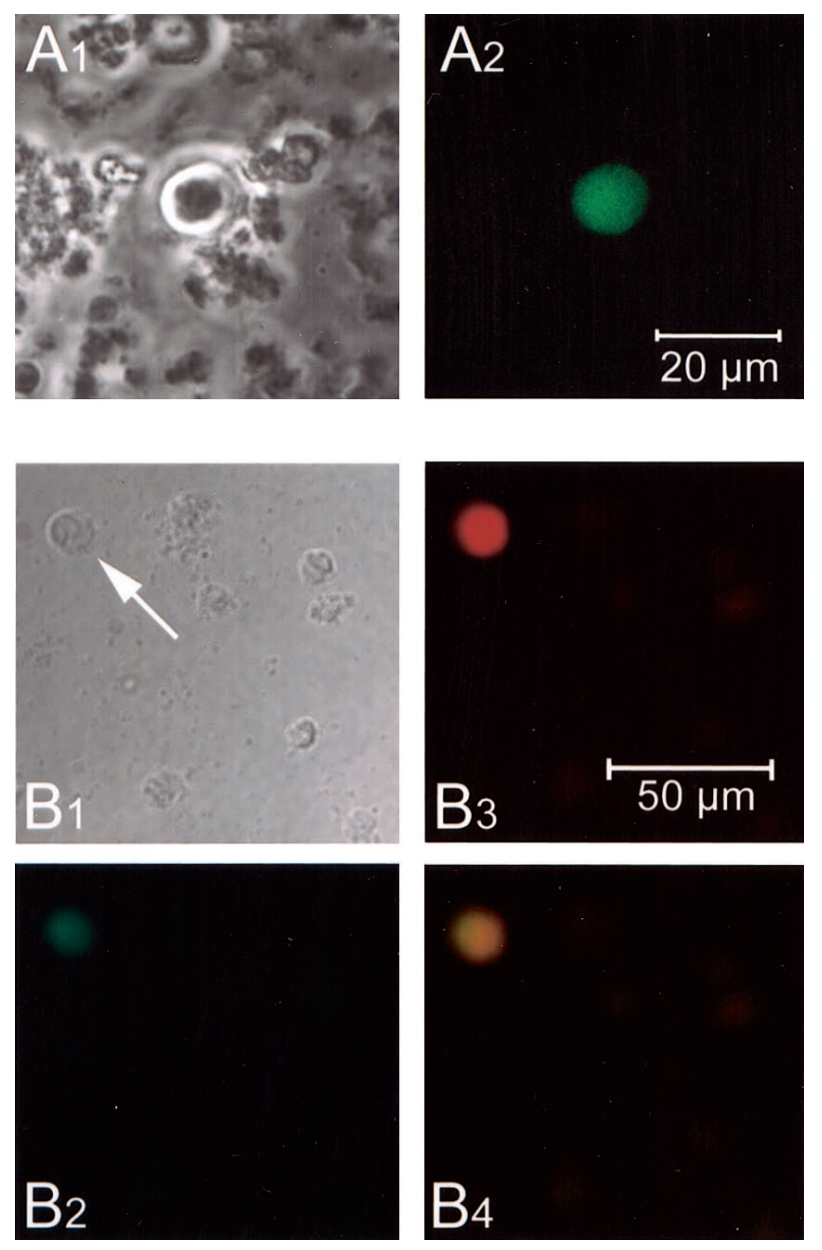

Figure 2. Identification of isolated GnRH-EGFP neurons. $A_{1}$, Phasecontrast image of an isolated, live GnRH-EGFP neuron. Note the round, phase-bright appearance and cellular debris. $A_{2}$, Fluorescence view of the same GnRH-EGFP neuron. Scale bar, $20 \mu \mathrm{m}$. Images were captured at $40 \times$ with a confocal microscope (Zeiss) $18 \mathrm{hr}$ after dissociation. $B_{1}$, Differential interference contrast image of neurons after acute dissociation. The same field was visualized with a GFP filter (Chroma Technology Corp., Brattleboro, VT) $\left(B_{2}\right)$ and a rhodamine filter $\left(B_{3}\right)$. Note that only one neuron shows EGFP fluorescence, and that same neuron is the only one immunoreactive for $\mathrm{GnRH}\left(B_{4}\right)$. Images were captured at $40 \times$ with a Zeiss Axioplan 2 imaging system. Scale bar, $50 \mu \mathrm{m}$.

ous activity varied from absent to random. In $70 \%$ (7 of 10) of cells, however, bursts (arbitrarily defined as a period with a firing frequency of $2-20 \mathrm{~Hz})$ appeared phasic $(n=7)$ (Fig. $3 A)$, with brief bursts (2-20 action potentials) of activity separated by $1-10$ sec. Twenty-eight percent (5 of 18) of neurons also demonstrated bursting activity in whole-cell configuration (Fig. 3B). Bursting activity was present when cells were at a resting membrane potential of -50 to $-55 \mathrm{mV}$. The bursting activity was similar to that noted in cell-attached configuration (Fig. $3 A, B$ ) and was accompanied by small oscillations in membrane potential (Fig. $3 C$ ). These oscillations were most likely not attributable to synaptic input, because bathing the neuron in CNQX, APV, and bicuculline did not affect the membrane oscillations (see Materials and Methods). At more depolarized potentials (approximately $-45 \mathrm{mV}$ ), firing usually became continuous, and cell health declined. At more hyperpolarized potentials (up to $-80 \mathrm{mV}$ ), longer bursts of action potentials lasted from seconds to minutes and were separated by long periods of no activity ( $n=9$ of 15) 
A

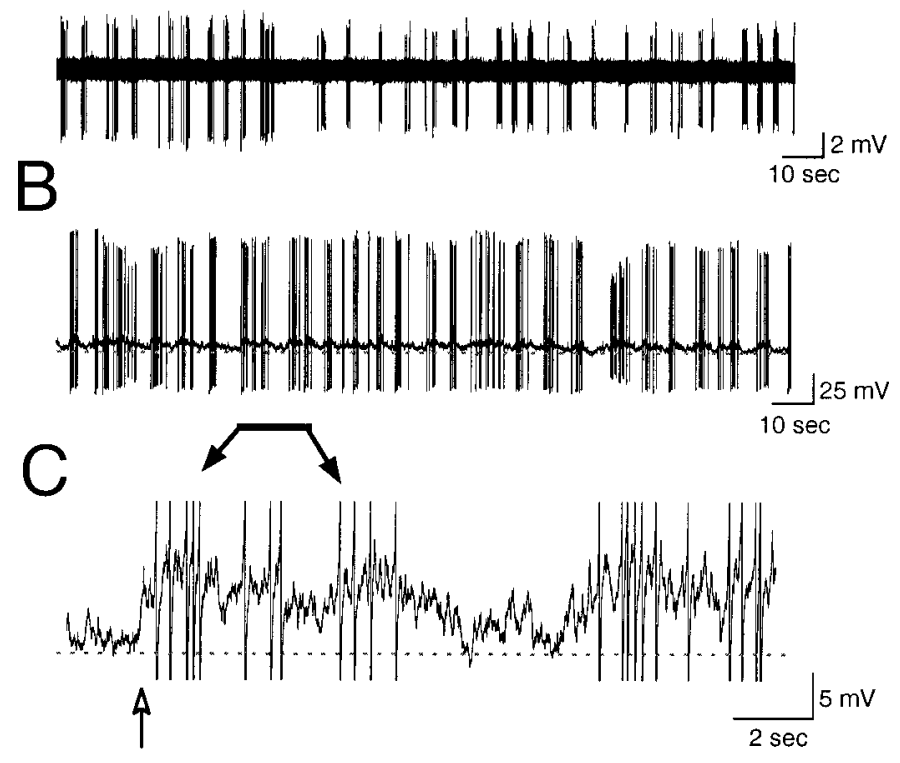

Figure 3. Spontaneous bursting activity. Representative patterns of repetitive bursts in cell-attached mode $(A)$ and in whole-cell mode $(B)$. Both traces demonstrate repetitive bursts. $C$, A high-gain, filtered trace of a region in $B$ (indicated by the bar) demonstrating the oscillation of membrane potential that accompanied each burst. The baseline indicates $-60 \mathrm{mV}$ in $B$ and $C$. The action potentials in $C$ are cropped, and filtering resulted in the clipping of an action potential (arrow). $A$ and $B$ represent 3 min of activity; $C$ represents $18 \mathrm{sec}$. The neuron in $A$ was obtained from a P21 animal. $B$ and $C$ were from a P17 animal.

(Figs. 4, 5). Episodes of bursting activity were arbitrarily defined as periods of activity with long intervals $(>1 \mathrm{~min})$ of virtual silence in between. Because of the obvious distinction between episodic activity and intervening silence (Figs. 4, 5), no attempt was made to include a lower rate limit in our definition. Multiple episodes were observed in $67 \%$ of cells with episodic activity (Figs. 4, 5).

Episodes were typically observed in neurons that were at a resting membrane potential more negative than $-60 \mathrm{mV}$ on break-in and also in neurons that were hyperpolarized with current injection. Most episodic activity occurred at membrane potentials between -65 and $-80 \mathrm{mV}$. However, episodic activity could also occur at a membrane potential of $-55 \mathrm{mV}$ (Fig. $5 F$ ). Activity was variable (Fig. 5), with 1-20 min of relative inactivity between episodes. In addition, activity within an episode was variable, ranging from 0.5 to $10 \mathrm{~Hz}$. Episodes were typically accompanied by depolarizing oscillations of membrane potential (Fig. 4). Oscillations that did not result in activity were also observed.

\section{GnRH-EGFP neuron membrane properties}

The passive membrane properties of GnRH-EGFP neurons consisted of resting membrane potentials of $52.5 \pm 2.62 \mathrm{mV}(n=16)$, input resistance of $2.44 \pm 0.23 \mathrm{G} \Omega$, membrane time constant of $23.9 \pm 2.91 \mathrm{msec}(n=11)$, and membrane capacitance of $7.82 \pm$ $1.01 \mathrm{pF}(n=11)$. Thus, the passive membrane properties of EGFP-GnRH neurons were typical of hypothalamic neurons, which was confirmed by recording from isolated non-EGFP neurons that had resting membrane potentials of $-54.4 \pm 3.71(n=$ $8)$, input resistance of $3.1 \pm 0.26(n=4)$, and membrane capacitance of $10.5 \pm 2.79(n=8)$. The small capacitance of the isolated EGFP-GnRH or non-GnRH neurons most likely reflects the fact that these cells are small spheres without extended neurites. To assess whether the GnRH-EGFP neurons formed distinct classes or groups based on their intrinsic electrophysiological properties, we analyzed evoked action potentials and voltage responses to $200 \mathrm{msec}$ hyperpolarizing and depolarizing current pulses. Depolarizing and hyperpolarizing current pulses (200 msec) generated a linear voltage-current plot (Fig. 6A). The ratio of $V_{20} \mathrm{msec}$ to $V_{190 \mathrm{msec}}$ indicates the amount of voltage rectification, in that marked rectification (for which the voltage at the beginning of the pulse is much smaller than that at the end of the pulse) will produce a ratio $\ll 1.0$. Little or no rectification was noted, as indicated by an average ratio of $V_{20 \mathrm{msec}}$ to $V_{190 \mathrm{msec}}$ of $0.65 \pm 0.07(n=11)$. The waveform of the action potential from GnRH-EGFP neurons was also typical (Fig. 6B), with an amplitude of $95 \pm 5.4 \mathrm{mV}$, threshold of $-31.3 \pm 3.7 \mathrm{mV}$, hyperpolarizing afterpotential of $-64.0 \pm 2.6 \mathrm{mV}$ with respect to $0 \mathrm{mV}$, and duration at half-amplitude of $1.21 \mathrm{msec}(n=11)$. Thus, in their passive membrane properties and action potential characteristics, the GnRH-EGFP neurons appeared to be relatively homogeneous and typical of hypothalamic neurons. A comparison of the firing properties of non-EGFP hypothalamic neurons indicated a higher incidence of quiescent neurons (three of six non-EGFP cells tested), yet the spontaneously active neurons fired at 2.5-50 $\mathrm{Hz}$ (three of six non-EGFP cells) and exhibited no obvious differences in the waveform of the action potential (data not shown).

\section{Response to excitatory amino acids}

Application of glutamate or NMDA always depolarized the membrane potential and increased the activity of GnRH-EGFP neurons (Fig. 7). Linear regression analysis demonstrated that the amplitude of the agonist-evoked current response was correlated with the amplitude of the membrane depolarization $(r=0.99$; $p=0.0006 ; n=5)$, suggesting heterogeneity in the level of expression of ionotropic glutamate receptors.

Whole-cell responses to rapid perfusion of glutamate were evoked from neurons attached to the bottom of the culture dish and neurons lifted by the recording pipette. Application of glutamate evoked inward currents (Fig. $8 A$ ) in all neurons. The average glutamate-evoked current response was $26 \pm 6.4 \mathrm{pA}$. Responses were small in $68 \%$ of neurons $(1-15 \mathrm{pA} ; n=23)$ but were substantially larger in $32 \%$ of neurons $(25-185 \mathrm{pA} ; n=11$ ) (Fig. $8 C)$. Small and large currents could be evoked in separate neurons from a single animal, and the size of the glutamate-evoked current did not depend on the postnatal age of the animal or the brain region from which the neuron was isolated. Linear regression analysis indicated that capacitance was weakly correlated with the current response $(r=0.5 ; p=0.004 ; n=30)$. Glutamateevoked responses in non-EGFP hypothalamic neurons and cortical neurons from the same transgenic animals were comparable with the large responses in the GnRH-EGFP animals (mean of $53.8 \pm 9.58 \mathrm{pA}$; range of $34-90 \mathrm{pA} ; n=7$ ).

Rapid application of NMDA also evoked current responses in GnRH-EGFP neurons (Fig. 8A). NMDA-evoked currents were observed in all neurons tested $(n=6)$ and were observed in neurons with both small and large responses to glutamate. In addition, cyclothiazide markedly potentiated the glutamateevoked inward current (Fig. 8B), indicating a substantial contribution of the flip splice isoform of AMPA receptors to the glutamate response. The mean peak response to $10 \mathrm{~mm}$ glutamate in the presence of $100 \mu \mathrm{M}$ cyclothiazide was 4.6 times the mean 

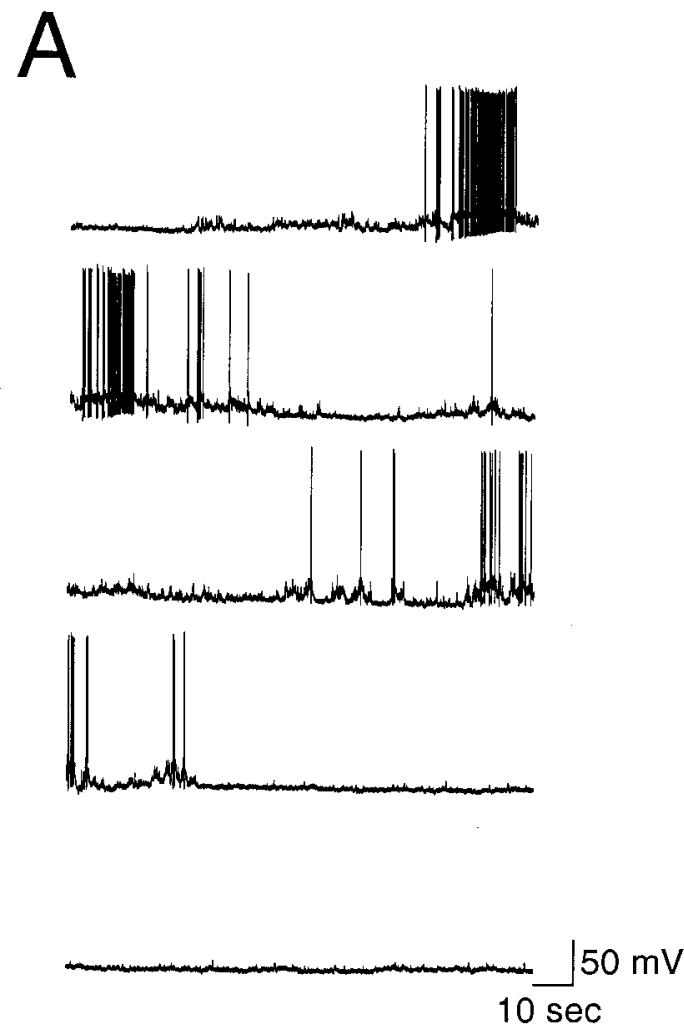

B
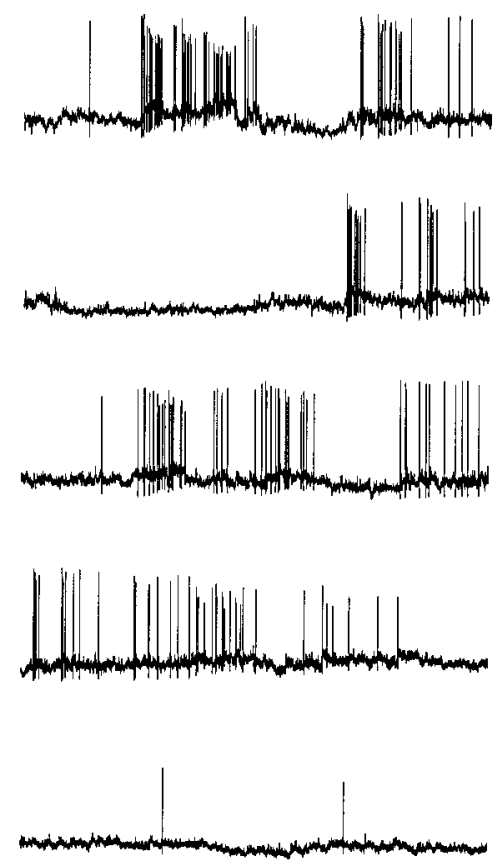

Figure 4. Episodic activity. $A, B$, Ten minute traces from two neurons demonstrating that spontaneous bursts can occur in episodes of activity that are separated by minutes of silence. The neuron in $B$ was more active (see histogram in Fig. $5 B$ ). $A$ represents the region indicated by the bar in the histogram in Figure $5 A$, and $B$ represents the region in Figure $5 B$. Both neurons were hyperpolarized to $-75 \mathrm{mV}$ by current injection. Note the long periods of inactivity, the multiple bursts, and the oscillations in membrane potential in both traces. The data shown in $A$ was obtained from a P17 mouse (same neuron as in Fig. $3 B, C$ ), whereas the data shown in $B$ was obtained from a P21 mouse.
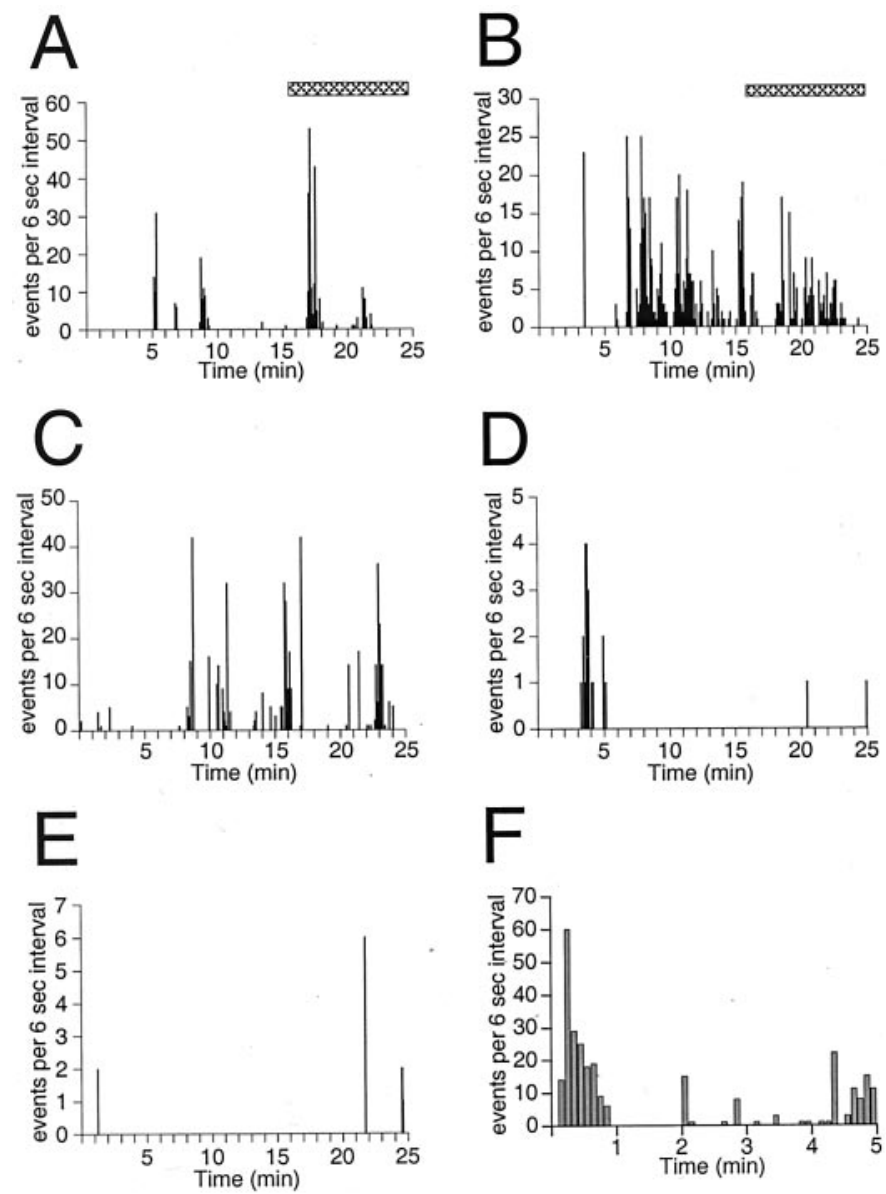

Figure 5. Variability in episodic activity. Frequency histograms illustrating spontaneous episodic activity in six GnRH-EGFP neurons ( $25 \mathrm{~min}$ of recording is shown in $A-E$ and $5 \mathrm{~min}$ in $F$ ). The number of events in each $6 \mathrm{sec}$ interval is plotted versus time. Note the variability in activity level among neurons. Also note multiple episodes of bursting separated by periods of inactivity extending up to $20 \mathrm{~min}$. The duration of episodic activity in $A-E$ ranged from 28 to $70 \mathrm{~min}$, and length of record in $F$ was $11 \mathrm{~min}$. Raw data from the neurons shown in $A$ and $B$ (hatched bars) were also presented in Figure 4. All recordings were from P17-P23 mice: $A$, $\mathrm{P} 17 ; B, \mathrm{P} 21 ; C, \mathrm{P} 21$ (same animal as $B$ ); $D, \mathrm{P} 22 ; E, \mathrm{P} 23 ; F, \mathrm{P} 21$.

peak response to $10 \mathrm{~mm}$ glutamate alone $(n=5)$. Responses to rapid application of $10 \mathrm{~mm}$ GABA were found in 15 of 15 cells tested, but the role of GABA receptors was not further studied.

\section{DISCUSSION}

Acute dissociation of hypothalamic slices from prepubertal GnRH-EGFP transgenic mice produced single neurons suitable for extended whole-cell and cell-attached recordings. Individual GnRH neurons consistently generated repetitive bursts of action potentials separated by periods of silence that could each last for minutes. Rapid application of either glutamate or NMDA depolarized GnRH-EGFP neurons and evoked repetitive firing, although agonist-evoked currents of most GnRH neurons were small (i.e., a few picoamperes). This is in contrast to the responses of cortical and non-GnRH hypothalamic neurons (tens of picoamperes) (Spergel et al., 1999, Kuehl-Kovarik et al., 2000). Cyclothiazide enhanced the amplitude and markedly reduced desensitization of the glutamate-induced inward currents, consistent with the participation of the flip splice isoform of AMPA receptors in the glutamate-evoked responses (Partin et 


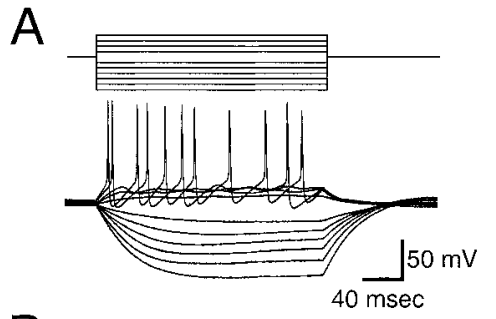

B

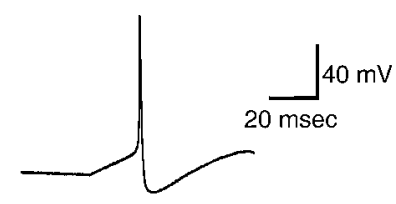

Figure 6. Membrane properties of GnRH-EGFP neurons. A, Typical responses to hyperpolarizing and depolarizing $200 \mathrm{msec}$ current pulses of $-10,-20,-30,-40,-50$, and $-60 \mathrm{pA}$ and $+10,+20,+30$, and $+40 \mathrm{pA}$. This neuron had a resting membrane potential of $-58 \mathrm{mV}$. Responses to hyperpolarization did not rectify and, in this example, demonstrated a $V_{20}$ $\mathrm{msec} / V_{190 \mathrm{msec}}$ ratio of 0.49 . Depolarization resulted in the firing of a train of action potentials. $B$, Waveform of a typical action potential, taken from the same neuron as shown above, during a $20 \mathrm{pA}$ depolarizing current pulse of 200 msec duration.

\section{$A_{1} \quad B_{1}$}
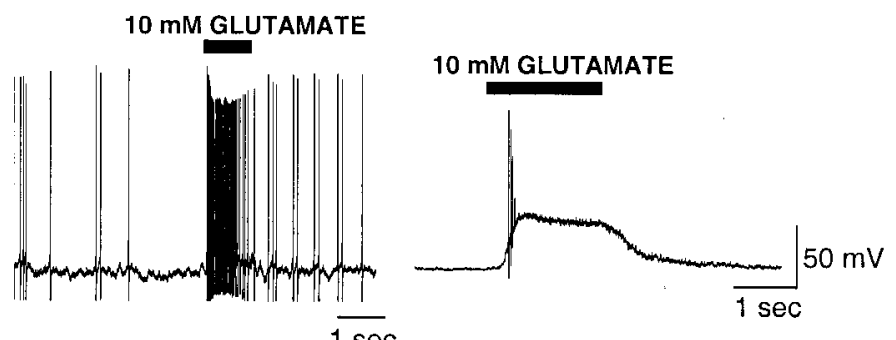

$\mathrm{A}_{2}$
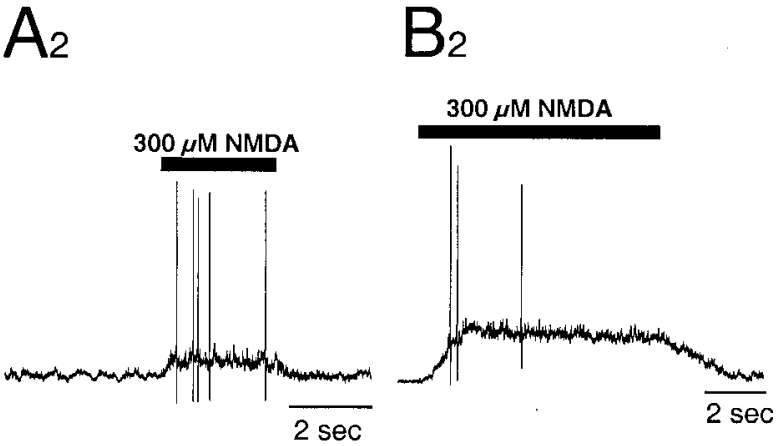

Figure 7. Glutamate- and NMDA-evoked activity. Representative patterns of activity recorded in current-clamp mode during application of 10 mM glutamate $\left(A_{1}, B_{1}\right)$ or $300 \mu \mathrm{M}$ NMDA $\left(A_{2}, B_{2}\right) . A_{1}$ and $A_{2}$ are depolarizations observed in a GnRH-EGFP neuron with a smallamplitude current response ( $5 \mathrm{pA}$ ) to $10 \mathrm{~mm}$ glutamate (see Fig. $8 A$ ). $B_{1}$ and $B_{2}$ are depolarizations from a neuron with a larger $(80 \mathrm{pA})$ current response. Application of agonist increased firing and depolarized the membrane in all cases. Neurons were isolated from the brain of a P23 mouse.

al., 1993). These experiments support the hypothesis that the responses of GnRH neurons to glutamate involve both NMDA and AMPA receptors.

\section{Isolation and properties of GnRH neurons}

Previous work on GnRH-EGFP mice found that virtually all GFP-expressing neurons were immunocytochemically positive
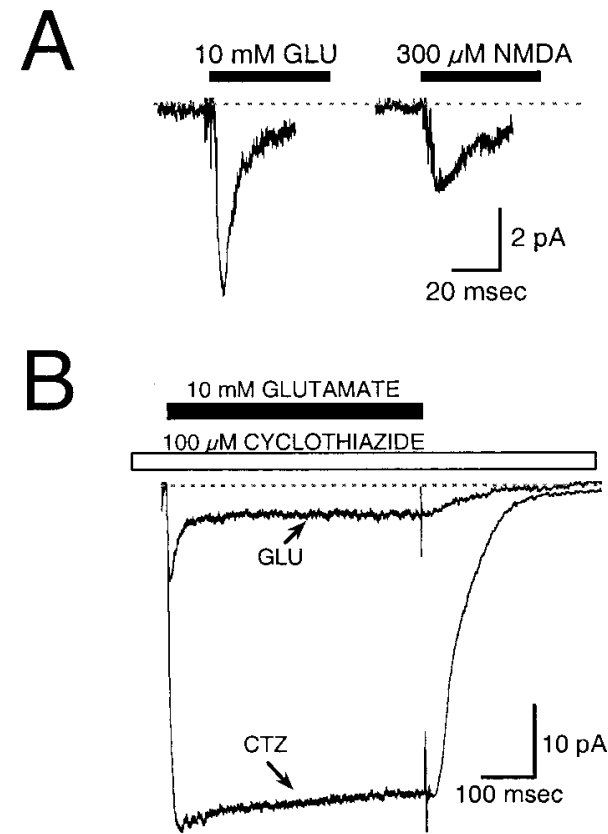

C

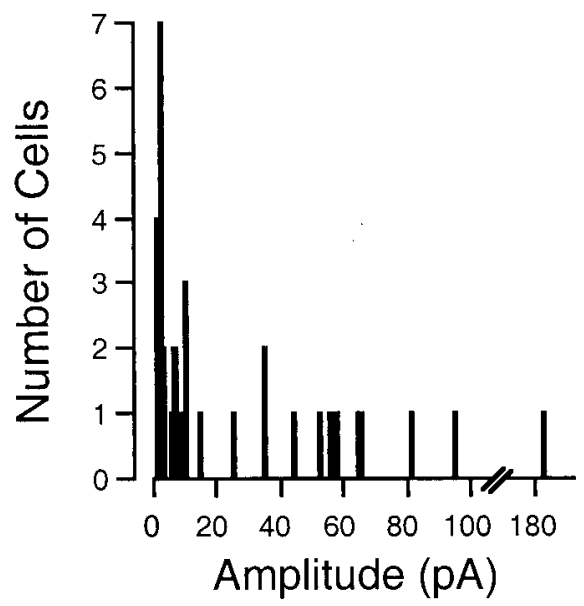

Figure 8. Excitatory amino acid-evoked currents. $A$, Representative inward currents evoked by the $500 \mathrm{msec}$ application of $10 \mathrm{~mm}$ glutamate or $300 \mu \mathrm{M}$ NMDA. Currents were recorded from a GnRH-EGFP neuron lifted off the bottom of the culture dish. This neuron was isolated from a P23 mouse. Each trace represents a single application of agonist. $B$, Inward current evoked by the $500 \mathrm{msec}$ application of $10 \mathrm{~mm}$ glutamate ( $G L U)$, superimposed on the response to $10 \mathrm{~mm}$ glutamate and $100 \mu \mathrm{M}$ cyclothiazide $(C T Z)$. Note the large potentiation and absence of desensitization of the glutamate response by cyclothiazide. Currents were recorded from a GnRH-EGFP neuron that was attached to the bottom of the dish. The neuron was isolated from the brain of a P17 mouse. Traces are the average of 5-10 records. $C$, Frequency histogram illustrates the response amplitude to glutamate in 34 cells. Note the large number of neurons with a small $(<15 \mathrm{pA})$ response.

for GnRH, and 84-94\% of all GnRH-positive neurons expressed GFP (Suter et al., 2000a). The immunocytochemical results are consistent with these observations and indicate that the recorded neurons expressed GnRH. Sim and coworkers (2001) suggested that GFP expression in transgenic mice injures the electrophysiological properties of GnRH neurons, but this has not been seen in other neurons (Lagrange et al., 1995; Z huo et al., 1997; Spergel et al., 1999, 2001; Suter et al., 2000a,b; Sawamoto et al., 2001).

GnRH neurons were isolated from slices that extended from 
the septum to the mediobasal hypothalamus and thus could be considered heterogeneous, but none of the characteristics studied here showed an obvious association with the location from which the neurons were isolated. Based primarily on the responses to injected current pulses during whole-cell recording in slices, Sim and coworkers (2001) have reported three populations of GnRH neurons in juvenile mice. The present experiments were performed on prepubertal mice (P17-P25), and experiments with 200 msec current pulses similar to Sim and coworkers (2001) did not reveal obvious subgroups, consistent with the findings of Spergel and coworkers (1999).

\section{Firing patterns: burst generation}

A fundamental concept concerning the electrophysiological properties of neuroendocrine cells is that a bursting pattern of action potentials is important for hormone secretion (Andrew and Dudek, 1983, 1984; Dudek et al., 1989, 2000; Bourque et al., 1993). This concept in mammalian neuroendocrine cells has been developed primarily from studies of the magnocellular system, which is comprised of the vasopressinergic and oxytocinergic neurons that project to the posterior pituitary (Poulain and Wakerley, 1982; Armstrong et al., 1994; Armstrong, 1995, Hatton and Li, 1998). Magnocellular neuroendocrine cells have oscillations in membrane potential and depolarizing afterpotentials (DAPs) that summate (Andrew and Dudek, 1983, 1984) (for review, see Dudek et al., 1989; Armstrong et al., 1994; Li et al., 1995). We observed slow oscillations in membrane potential that seemed to be responsible for the burst discharges, but DAPs did not appear to contribute to the bursts. Recently, observations of spontaneous elevations in intracellular calcium in cultured embryonic GnRH neurons from monkey nasal placode suggest that individual GnRH neurons generate spontaneous bursts of activity (Terasawa et al., 1999b; Terasawa, 2001). Pulsatile GnRH release may arise from the synchronization of these bursts. Similarly, other groups have recently performed long-term, multisite recordings on GT1-7 cells, demonstrating that overall patterns of firing activity are derived from the sum of multiple, independent active units (i.e., GnRH neurons) within a network (Funabashi et al., 2001; Nunemaker et al., 2001).

Our experiments demonstrate that mechanisms capable of generating burst discharges are present in individual GnRH neurons. Models of the possible relationship between the bursting of individual neurons and the pulsatile release of GnRH hormone are shown in Figure 9. The "independent" model assumes that each neuron generates spontaneous bursts of activity that allow hormone release that is not necessarily synchronous. The "coupled" model assumes that the GnRH neurons communicate directly with one another through either gap-junctions or through cellular factors released by GnRH neurons and to which other GnRH neurons can respond, leading to pulsatile release of hormone. The "triggered" model assumes that a non-GnRH "master" cell with pulse-generating properties signals to the entire GnRH neuron population, allowing coordinated firing and thereby coordinated release of hormone. Figure $9, B$ and $C$, demonstrates, modeling data from Figure 5, that one possible outcome of independent neuronal activity can be "synchronous," pulsatile waves of hormone release. Thus, the data presented from isolated EGFP$\mathrm{GnRH}$ neurons do not exclude any of the three models presented in Figure $9 A$.

\section{Firing patterns: episodic activity}

Multiple-unit recordings from the hypothalamus support the hypothesis that pulsatile secretion of GnRH derives from synchro-

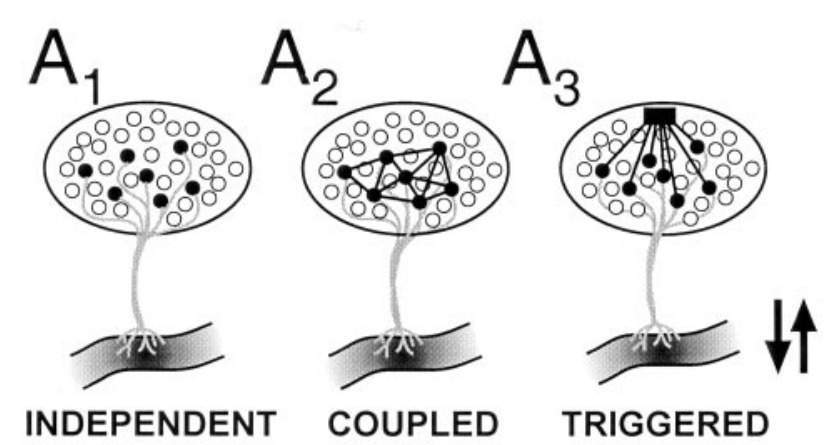

8
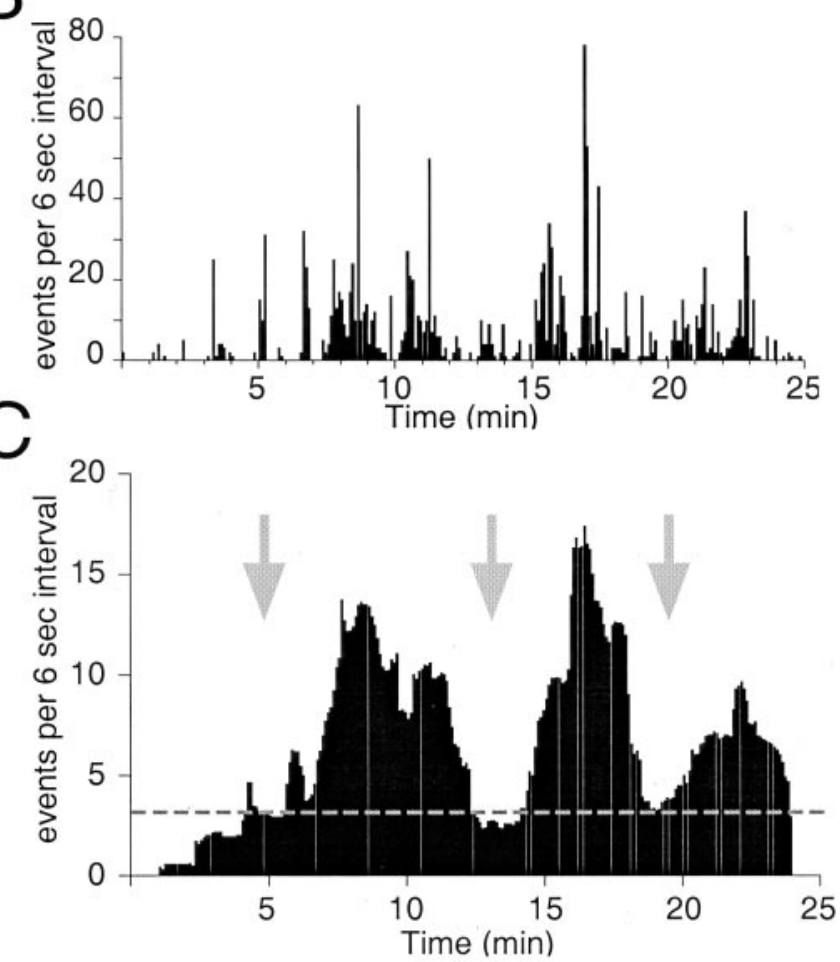

Figure 9. Hypothetical relationship between action potentials of isolated GnRH neurons and multiple-unit activity of the GnRH population responsible for pulsatile release of GnRH. It is hypothesized that GnRH pulsatility arises from overlapping episodes of bursts of action potentials in many GnRH neurons. $A$, Schematic diagram depicting three possible models for how GnRH neurons could fire as a network: independently (Terasawa, 2001), coupled (Witkin et al., 1995; Hosny and Jennes, 1998; Hu et al., 1999), or triggered by one or a few divergent neurons with pulse-generating properties (van den Pol and Trombley, 1993; Boudaba et al., 1997). In all three cases, the electrical activity will cause hormone release at the median eminence. GnRH neurons are depicted as filled circles; the pulse-generating cell is depicted as a filled square; arrows indicate pulses of GnRH release. $B$, The binned activities of five independent neurons (taken from Fig. 5) were summed into a single profile. The most active neuron (Fig. $5 B$ ) dominates the summed activity, and the other four cells also shape its profile. "Pulses" of activity emerge from this profile. $C$, The data in $B$ were smoothed by calculating the moving average of 20 data points around each data point. We speculate that the smoothing function could represent an averaging of the activity of $800-1000$ GnRH neurons in the hypothalamus and would yield pulses of electrical activity that mimic the resultant pulsatile release of hormone. In this scheme, the dotted line represents a baseline level of hormone that would be constitutively released, and the three major waves of activity represent pulsatile hormone release. The arrows indicate where, in the COUPLED model $\left(A_{2}\right)$, there would be synchronized activity, or, in the TRIGGERED model $\left(A_{3}\right)$, the release of glutamate onto many GnRH neurons would initiate a pulse of activity and hormone release. The averaged data in $C$, however, actually represent the INDEPENDENT activity of five neurons, as depicted in $A_{l}$. 
nized episodes of electrical activity involving GnRH neurons (Kawakami et al., 1982; Wilson et al., 1984; Mori et al., 1991; Cardenas et al., 1993). Using this same transgenic mouse, longlasting episodes of electrical activity containing repetitive burst discharges were observed in whole-cell recordings in brain slices from mice that were 26-65 d old (Suter et al., 2000b). In these studies, spike activity was defined as occurring when the firing rate was $\geq 4 \mathrm{~Hz}$, and only single episodes of activity were observed in each recording. Our studies extend this work by showing that a range of levels of firing appear to contribute to the bursts and prolonged episodes of activity, and that these electrophysiological properties are present in juvenile mice by the time they are weaned (15-25 d of age). The lack of multiple episodes of activity (Suter et al., 2000b) left open the possibility that an episode arose from dialysis of the intracellular compartment. However, we observed burst discharges and episodic firing in cell-attached recordings (i.e., "on cell"), a recording configuration in which dialysis would not be expected to occur. The observation of multiple repetitive episodes in single GnRH neurons is also evidence against the possibility that an episode of activity arises from a recording-induced deterioration of the cell.

In the female rat, several hypothalamic changes occur during the transition from the infantile (P8-P12) to the juvenile (P21P32) stage of development (Ojeda et al., 1980). During this transition, there is an increase in: the ratio of "spiny" to "smooth" morphology in GnRH neurons (Wray and Hoffman, 1986), the capacity to release GnRH (Andrews and Ojeda, 1978; Ojeda et al., 1980), and sensitivity to steroid feedback (Ojeda and Ramirez, 1973; Ojeda et al., 1975; Andrews et al., 1981). Thus, variability in the GnRH firing pattern may be attributable to the maturational events occurring at this time. Our studies on acutely isolated $\mathrm{GnRH}$ neurons from prepubertal mice strongly support the hypothesis that individual GnRH neurons at this developmental stage have the intrinsic mechanisms capable of generating the activity pattern that would be expected to underlie the pulsatile secretion of hormone. We aimed to record from mice before puberty, with the view that the onset of GnRH pulsatile release during puberty would be contingent on the appropriate organization of the neuronal network. The question of how the population of GnRH neurons is synchronized to coordinate hormone secretion will require additional investigation.

\section{Responses of GnRH neurons to glutamate}

Glutamate is thought to be the primary excitatory transmitter in the mammalian brain, including the neuroendocrine hypothalamus (for review, see van den Pol et al., 1990). Several studies have suggested that glutamate plays a critical excitatory role in the GnRH system (Schainker and Cicero, 1980; Arslan et al., 1988; Ondo et al., 1988; Bourguignon et al., 1989) (for review, see Brann and Mahesh, 1997). However, the direct effect of glutamate on GnRH neurons has not been well described, and the effect of glutamate on GT1-7 cells is controversial (Spergel et al., 1994; Mahesh et al., 1999). Unlike cortical neurons, which have large responses to rapid application of $10 \mathrm{~mm}$ glutamate (KuehlKovarik et al., 2000), most GnRH neurons generated small inward currents. Similar findings were seen in excised patch experiments, for which the peak amplitude of the glutamate-evoked current was 10 -fold smaller for GnRH neurons than non-GnRH neurons in the same slice (Spergel et al., 1999). Our data show that glutamate is likely to serve as the primary excitatory transmitter in this neuroendocrine system, because glutamate (and NMDA) evoked robust firing of action potentials in isolated
GnRH neurons. Furthermore, a small proportion of the GnRHEGFP population did generate relatively large inward currents in response to the application of glutamate. The relatively small responses to glutamate and NMDA suggest low expression of AMPA and NMDA receptors, which may account for the previous lack of anatomical evidence for these receptor mRNAs and proteins in GnRH neurons (Abud et al., 1995; Eyigor and Jennes, 1996; Gore et al., 1996; Simonian and Herbison, 2001). However, our findings are significant because it has been reported that GnRH neurons have few synaptic inputs, and physiologically relevant responses must be evoked by these inputs (Witkin et al., 1995). Our findings are consistent with studies demonstrating that injection of NMDA stimulates release of GnRH (Gay and Plant, 1987). Therefore, both AMPA and NMDA receptors would be expected to mediate EPSCs of GnRH neurons, although the relative importance of these receptors at different stages of development and under different hormonal conditions will require additional study.

\section{Conclusion}

These experiments indicate that the GnRH-EGFP mouse can be used to record from acutely isolated $\mathrm{GnRH}$ neurons. Individual neurons could be studied relatively soon after isolation, so that possible culture-induced changes in electrophysiological properties were minimized. We found a rich repertoire of firing patterns that could represent the prolonged episodes of burst discharges that hypothetically underlie pulsatile secretion of GnRH. Additional research with this preparation offers the potential to identify the cellular mechanisms that generate the coordinated activation of the GnRH system to mediate secretion of this critical hormone. Our experiments further implicate glutamate, acting on both AMPA and NMDA receptors, as an important excitatory transmitter in this neuroendocrine system, possibly contributing to the activation of endogenous bursts of action potentials.

\section{REFERENCES}

Abud R, Smith MS (1995) Do GnRH neurons express the gene for the NMDA receptor? Brain Res 690:117-120.

Andrew RD, Dudek FE (1983) Burst discharge in mammalian neuroendocrine cells involves an intrinsic regenerative mechanism. Science 221:1050-1052.

Andrew RD, Dudek FE (1984) Analysis of intracellularly recorded phasic bursting by mammalian neuroendocrine cells. J Neurophysiol 51:552-566.

Andrews WW, Ojeda SR (1978) The control of LH release in prepubertal female rats: indirect evidence for an enhanced ability of the hypothalamus to release LHRH as the pituitary responsiveness to LHRH declines. J Endocrinol 78:281-282.

Andrews WW, Mizejewski GJ, Ojeda SR (1981) Development of estradiol positive feedback on $\mathrm{LH}$ release in the female rat: a quantitative study. Endocrinology 109:1404-1413.

Armstrong WE (1995) Morphological and electrophysiological classification of hypothalamic supraoptic neurons. Prog Neurobiol 47:291-339.

Armstrong WE, Smith BN, Tian M (1994) Electrophysiological characteristics of immunochemically identified rat oxytocin vasopressin neurons in vitro. J Physiol (Lond) 475:115-128.

Arslan M, Pohl CR, Plant TM (1988) DL-2-amino-5phosphonopentanoic acid, a specific $N$-methyl-D-aspartic acid receptor antagonist, suppresses pulsatile LH release in the rat. Neuroendocrinology 47:465-468.

Barry J, Hoffman GE, Wray S (1985) LHRH-containing systems. In: Handbook of chemical neuroanatomy (Bjorklund A, Hokfelt T, eds), pp 166-215. New York: Elsevier.

Boudaba C, Schrader LA, Tasker J (1997) Physiological evidence for local excitatory synaptic circuits in the rat hypothalamus. J Neurophysiol 77:3396-3400.

Bourguignon JP, Gerard A, Franchimont P (1989) Direct activation of gonadotropin-releasing hormone secretion through different receptors to neuroexcitatory amino acids. Neuroendocrinology 49:402-408.

Bourque CW, Oliet SH, Kirkpatrick K, Richard D, Fisher TE (1993) Extrinsic and intrinsic modulatory mechanisms involved in regulating 
the electrical activity of supraoptic neurons. Ann NY Acad Sci 689:512-519.

Brann DW, Mahesh VB (1997) Excitatory amino acids: evidence for a role in the control of reproduction and anterior pituitary hormone secretion. Endocrin Rev 18:678-700.

Branshaw JL, Hsu SF, Jackson MB (1998) Membrane excitability and secretion from peptidergic nerve terminals. Cell Mol Neurobiol $18: 45-63$.

Cardenas H, Ordog T, O’Byrne KT, Knobil E (1993) Single unit components of the hypothalamic multiunit electrical activity associated with the central signal generator that directs the pulsatile secretion of gonadotropic hormones. Proc Natl Acad Sci USA 90:9630-9634.

Drewe JA, Childs GV, Kunze DL (1988) Synaptic transmission between dissociated adult mammalian neurons and attached synaptic boutons. Science 241:1810-1813.

Dudek FE, Tasker JG, Wuarin JP (1989) Intrinsic and synaptic mechanisms of hypothalamic neurons studied with slice and explant preparations. J Neurosci Methods 28:59-69.

Dudek FE, Smith BN, Suter KJ, Wuarin JP (2000) Electrophysiology of hypothalamic neurons In: Neuroendocrinology in physiology and medicine (Conn PM, Freeman ME, eds), pp 527-539. Totowa, NJ: Humana.

Dudek FE, Pouliot WA, Kuehl-Kovarik C, DeFazio RA, Partin KM, Handa RJ, Moenter SM (2001) Electrophysiological analyses of GnRH neurons using a transgenic mouse model. In: Neuroplasticity, development, and steroid hormone action (Handa RJ, Hayashi S, Terasawa E, Kawata M, eds), pp 205-220. Boca Raton, FL: CRC.

Eyigor O, Jennes L (1996) Identification of glutamate receptor subtype mRNAs in gonadotropin-releasing hormone neurons in rat brain. Endocrine 4:133-139.

Franklin KBJ, Paxinos G (1997) The mouse brain in stereotaxic coordinates. New York: Academic.

Funabashi T, Suyama K, Uemura T, Hirose M, Hirahara F, Kimura F (2001) Immortalized gonadotropin-releasing hormone neurons (GT1-7 cells) exhibit synchronous bursts of action potentials. Neuroendocrinology 73:157-165.

Gay VL, Plant TM (1987) N-methyl-D,L-aspartate elicits hypothalamic gonadotropin-releasing hormone release in prepubertal male rhesus monkeys (Macaca mulatta). Endocrinology 120:2289-2296.

Goldsmith PC, Thind KK, Perera AD, Plant TM (1994) Glutamateimmunoreactive neurons and their gonadotropin-releasing hormoneneuronal interactions in the monkey hypothalamus. Endocrinology $134: 858-868$

Gore AC, Wu TJ, Rosenberg JJ, Roberts JL (1996) Gonadotropinreleasing hormone and NMDA receptor gene expression and colocalization change during puberty in female rats. J Neurosci 16:5281-5289.

Hatton GI, Li Z (1998) Mechanisms of neuroendocrine cell excitability. Adv Exp Med Biol 449:79-95.

Herbison AE (2001) Electrical properties of postnatal GnRH neurons in the mouse and their regulation by gonadal steroid hormones. In: Neuroplasticity, development, and steroid hormone action (Handa RJ, Hayashi S, Terasawa E, Kawata M, eds), pp 117-119. Boca Raton, FL: CRC.

Hosny S, Jennes L (1998) Identification of gap junctional connexin-32 mRNA and protein in gonadotropin-releasing hormone neurons of the female rat. Neuroendocrinology 67:101-108.

Hu L, Olson AL, Weiner RL, Goldsmith PC (1999) Connexin 26 expression and extensive gap junctional coupling in cultures of GT1-7 cells secreting gonadotropin-releasing hormone. Neuroendocrinology 70:221-227.

Kalra SP, Kalra PS (1983) Neural regulation of luteinizing hormone secretion in the rat. Endocrine Rev 4:311-351.

Kawakami M, Uemura T, Hayashi R (1982) Electrophysiological correlates of pulsatile gonadotropin release in rats. Neuroendocrinology 35:63-67.

Kay AR, Krupa DJ (1999) Acute isolation of neurons from the mature mammalian central nervous system. In: Current protocols in neuroscience (Crawley JN, Gerfen CR, McKay R, Rogawksi MA, Sibley DR, Skolnick P, Wray S, eds), pp 6.5.1-6.5.7. New York: Wiley.

Kuehl-Kovarik MC, Fails AD, Magnusson KR, Partin KM (2000) Kinetic analysis of NMDA responses from acutely dissociated cortical neurons during aging. Soc Neurosci Abstr 26:194.8.

Kusano K, Fueshko S, Gainer H, Wray S (1995) Electrical and synaptic properties of embryonic luteinizing hormone-releasing hormone neurons in explant cultures. Proc Natl Acad Sci USA 92:3918-3922.

Lagrange AH, Ronnekleiv OK, Kelly MJ (1995) Estradiol-17B and $\mu$-opioid peptides rapidly hyperpolarize $\mathrm{GnRH}$ neurons: a cellular mechanism of negative feedback? Endocrinology 136:2341-2344.

Li Z, Decavel C, Hatton GI (1995) Calbindin-D28k: role in determining intrinsically generated firing patterns in rat supraoptic neurons. J Physiol (Lond) 488:601-608.

Mahesh VB, Zamorano P, De Sevilla L, Lewis D, Brann DW (1999) Characterization of ionotropic glutamate receptors in rat hypothalamus, pituitary and immortalized gonadotropin-releasing hormone (GnRH) neurons (GT1-7 cells). Neuroendocrinology 69:397-407.
McCool BA, Botting SK (2000) Characterization of strychnine-sensitive glycine receptors in acutely isolated adult rat basolateral amygdala neurons. Brain Res 859:341-351.

Mellon PM, Windle JJ, Weiner RI (1991) Immortalization of neuroendocrine cells by targeted oncogenesis. Rec Prog Horm Res 47:69-93.

Mori Y, Nishihara M, Tanaka T, Shimizu T, Yamaguchi M, Takeuchi Y Hoshino K (1991) Chronic recording of electrophysiological manifestation of the hypothalamic gonadotropin-releasing hormone pulse generator activity in the goat. Neuroendocrinology 53:392-395.

Nishihara M, Takeuchi Y, Tanaka T, Mori Y (1999) Electrophysiological correlates of pulsatile and surge gonadotropin secretion. Rev Reprod $4: 110-116$.

Nunemaker CS, DeFazio RA, Geusz ME, Herzog ED, Pitts GR, Moenter SM (2001) Long-term recordings of networks of immortalized GnRH neurons reveal episodic patterns of electrical activity. J Neurophysiol 86:86-93

Ojeda SR, Ramirez VD (1973) Short-term steroid treatment on plasma LH and FSH in castrated rats from birth to puberty. Neuroendocrinology 13:100-114.

Ojeda SR, Kalra SP, McCann SM (1975) Further studies on the maturation of the estrogen negative feedback on gonadotropin release in the prepubertal female rat. Neuroendocrinology 18:242-255.

Ojeda SR, Andrews WW, Advis JP, Smith-White S (1980) Recent advances in the endocrinology of puberty. Endocrine Rev 1:228-257.

Ondo JG, Wheeler DD, Dom RM (1988) Hypothalamic site of action for $N$-methyl-D-aspartate (NMDA) on LH secretion. Life Sci 43:2283-2286.

Partin KM, Patneau DK, Winters CA, Mayer ML, Buonanno A (1993) Selective modulation of desensitization at AMPA versus kainate receptors by cyclothiazide and concanavalin A. Neuron 11:1069-1082.

Poulain DA, Wakerley JB (1982) Electrophysiology of hypothalamic magnocellular neurons secreting oxytocin and vasopressin. Neuroscience 7:773-808

Sagrillo CA, Grattan DR, McCarthy MM, Selmanoff M (1996) Hormonal and neurotransmitter regulation of $\mathrm{GnRH}$ gene expression and related reproductive behaviors. Behav Genetics 26:241-277.

Sawamoto K, Nakao N, Kakishita K, Ogawa Y, Toyama Y, Yamamoto A, Yamaguchi M, Mori K, Goldman SA, Itakura T, Okanao H (2001) Generation of dopaminergic neurons in the adult brain from mesencephalic precursor cells labeled with a nestin-GFP transgene. J Neurosci 11:3895-3903.

Schainker BA, Cicero TJ (1980) Acute stimulation of luteinizing hormone by parenterally administered $N$-methyl-D,L-aspartic acid in the male rat. Brain Res 184:425-437.

Selmanoff M (1997) Commentary on the use of immortalized neuroendocrine cell lines for physiological research. Endocrine J 6:1-3.

Silverman A, Livne I, Witkin JW (1994) The gonadotropin-releasing hormone (GnRH), neuronal systems: immunocytochemistry and in situ hybridization. In: The physiology of reproduction (Knobil E, Neill JD, eds), pp1683-1709. New York: Raven.

Silverman AJ, Jhamandas J, Renaud LP (1987) Localization of luteinizing hormone-releasing hormone $(\mathrm{LHRH})$ neurons that project to the median eminence. J Neurosci 7:2312-2319.

Sim JA, Skynner MJ, Herbison AE (2001) Heterogeneity in the basic membrane properties of postnatal gonadotropin-releasing hormone neurons in the mouse. J Neurosci 21:1067-1075.

Simonian SX, Herbison AE (2001) Differing, spatially restricted roles of ionotropic glutamate receptors in regulating the migration of GnRH neurons during embryogenesis J Neurosci 21:934-943.

Spergel DJ, Krsmanovic LZ, Stojilkovic SS, Catt KJ (1994) Glutmate modulates $\left[\mathrm{Ca}^{2+}\right] \mathrm{I}$ and gonadotropin-releasing hormone secretion in immortalized hypothalamic GT1-7 neurons. Neuroendocrinology 59:309-317.

Spergel DJ, Kruth U, Hanley DF, Sprengel R, Seeburg PH (1999) GABA- and glutamate-activated channels in green fluorescent proteintagged gonadotropin-releasing hormone neurons in transgenic mice. J Neurosci 19:2037-2050.

Spergel DJ, Kruth U, Shimshek DR, Sprengel R, Seeburg PH (2001) Using reporter genes to label selected neuronal populations in transgenic mice for gene promoter, anatomical, and physiological studies. Prog Neurobiol 6:673-686.

Suter KJ, Song WJ, Sampson TL, Wuarin JP, Saunders JT, Dudek FE, Moenter SM (2000a) Genetic targeting of green fluorescent protein to GnRH neurons: characterization of whole-cell electrophysiological properties and morphology. Endocrinology 141:412-419.

Suter KJ, Wuarin JP, Smith BN, Dudek FE, Moenter SM (2000b) Whole-cell recordings from preoptic/hypothalamic slices reveal burst firing in gonadotropin-releasing hormone neurons identified with green fluorescent protein in transgenic mice. Endocrinology 141:3731-3736.

Terasawa E (2000) Luteinizing hormone-releasing hormone (LHRH) neurons: mechanism of pulsatile LHRH release. Vitam Horm 63:91-129.

Terasawa E (2001) Pulse generation in LHRH neurons. In: Neuroplasticity, development, and steroid hormone action (Handa RJ, Hayashi S, Terasawa E, Kawata M, eds), pp 153-168. Boca Raton, FL: CRC. 
Terasawa E, Keen KL, Mogi K, Claude P (1999a) Pulsatile release of luteinizing hormone-releasing hormone (LHRH) in cultured LHRH neurons derived from the embryonic olfactory placode of the rhesus monkey. Endocrinology 140:1432-1441.

Terasawa E, Schanhofer WK, Keen KL, Luchansky L (1999b) Intracellular $\mathrm{Ca}^{2+}$ oscillations in luteinizing hormone-releasing hormone neurons derived from the embryonic olfactory placode of the rhesus monkey. J Neurosci 19:5898-5909.

Thind KK, Goldsmith PC (1995) Glutamate and GABAergic neurointeractions in the monkey hypothalamus: a quantitative immunomorphological study. Neuroendocrinology 61:471-485.

van den Pol AN, Trombley PQ (1993) Glutamate neurons in hypothalamus regulate excitatory transmission. J Neurosci 13:2829-2836.

van den Pol AN, Wuarin JP, Dudek FE (1990) Glutamate, the dominant excitatory transmitter in neuroendocrine regulation. Science 250:1276-1278.

Wetsel WC, Valenca MM, Merchenthaler I, Liposits Z, Lopez FJ, Weiner
RI, Mellon PL, Negro-Vilar A (1992) Intrinsic pulsatile secretory activity of immortalized luteinizing hormone-releasing hormonesecreting neurons. Proc Natl Acad Sci USA 89:4149-4153.

Wilson RC, Kesner JS, Kaufman JM, Uemura T, Akema T, Knobil E (1984) Central electrophysiological correlates of pulsatile luteinizing hormone secretion in the rhesus monkey. Neuroendocrinology 39:256-260.

Witkin JW, O'Sullivan H, Silverman AJ (1995) Novel associations among gonadotropin-releasing hormone neurons. Endocrinology $136: 4323-4330$

Wray S, Hoffman G (1986) Postnatal morphological changes in rat LHRH neurons correlated with sexual maturation. Neuroendocrinology 43:93-97.

Zhuo L, Sun B, Zhang CL, Fine A, Chiu SY, Messing A (1997) Live astrocytes visualized by green fluorescent protein in transgenic mice. Dev Biol 187:36-42. 